University of Nebraska - Lincoln

DigitalCommons@University of Nebraska - Lincoln

Faculty Papers and Publications in Animal

Science

Animal Science Department

March 2000

\title{
Genetic parameters among weight, prolificacy, and wool traits of Columbia, Polypay, Rambouillet, and Targhee sheep
}

C. M. Bromley

University of Nebraska-Lincoln

G. D. Snowder

U.S. Sheep Experimental Station, Dubois, ID

L. Dale Van Vleck

University of Nebraska-Lincoln, dvan-vleck1@unl.edu

Follow this and additional works at: https://digitalcommons.unl.edu/animalscifacpub

Part of the Animal Sciences Commons

Bromley, C. M.; Snowder, G. D.; and Van Vleck, L. Dale, "Genetic parameters among weight, prolificacy, and wool traits of Columbia, Polypay, Rambouillet, and Targhee sheep" (2000). Faculty Papers and Publications in Animal Science. 216.

https://digitalcommons.unl.edu/animalscifacpub/216

This Article is brought to you for free and open access by the Animal Science Department at DigitalCommons@University of Nebraska - Lincoln. It has been accepted for inclusion in Faculty Papers and Publications in Animal Science by an authorized administrator of DigitalCommons@University of Nebraska - Lincoln. 


\title{
Genetic parameters among weight, prolificacy, and wool traits of Columbia, Polypay, Rambouillet, and Targhee sheep ${ }^{1}$
}

\author{
C. M. Bromley ${ }^{*, 2,3}$, G. D. Snowder $\dagger$, and L. D. Van Vleck \\ *Department of Animal Science, University of Nebraska, Lincoln 68583-0908; USDA, ARS, \\ $\dagger$ U.S. Sheep Experimental Station, Dubois, ID 83423; and $¥$ Roman L. Hruska \\ U.S. Meat Animal Research Center, Lincoln 68583-0908
}

\begin{abstract}
Genetic parameters for Columbia, Polypay, Rambouillet, and Targhee sheep were estimated using REML with animal models for prolificacy, weight, and wool traits. All bivariate analyses included a covariance between additive genetic effects for the two traits plus appropriate additional covariances. Number of observations by breed ranged from 5,140 to 7,095 for prolificacy traits, from 7,750 to 9,530 for weight traits, and from 4,603 to 34,746 for wool traits. Heritability estimates ranged from .03 to .11 for prolificacy traits (litter size at birth and litter size at weaning), from .09 to .26 for weight traits (birth weight and average daily gain), and from .25 to .53 for wool traits (fleece weight, fleece grade and staple length). Estimates of direct genetic correlations among prolificacy and among weight
\end{abstract}

traits were positive and ranged from .58 to 1.00 and .18 to 1.00 , respectively. Estimates of direct genetic correlation between fleece weight and staple length were positive (.50 to .70) but were negative between fleece weight and fleece grade (-.60 to -.34$)$ and between staple length and fleece grade (-.72 and -.40). Prolificacy and wool traits were essentially uncorrelated. Weight and prolificacy traits were slightly positively correlated. Weight traits had a moderate positive direct genetic correlation with fleece weight and staple length, but were uncorrelated with fleece grade. These estimates of genetic parameters between prolificacy, weight, and wool traits can be used to construct multiple-trait selection indexes for dual-purpose sheep.

Key Words: Genetic Correlation, Growth, Heritability, Reproduction

(C)2000 American Society of Animal Science. All rights reserved.

J. Anim. Sci. 2000. 78:846-858

\section{Introduction}

When a species produces more than one commodity, such as meat and wool, as is the case with dual-purpose sheep, benefits from genetic response are expressed as increased profitability due to improvement in wool production, reproductive ability, and lamb weight (Dickerson, 1970; Lasley, 1978; Nawaz et al., 1992; Sakul et al., 1994). In previous studies, correlations have been reported between lambing rate and various measures of wool traits (Shelton and Menzies, 1968; O Ferrall, 1976; Saboulard et al., 1995), between weight and wool traits (Lasley, 1978), between different wool measures (Iman et al., 1992), between ewe reproduction and

\footnotetext{
${ }^{1}$ Published as paper no. 12568, Journal Ser., Nebraska Agric. Res. Div., Univ. of Nebraska, Lincoln 68583-0908.

${ }^{2}$ Current address: Genetic Epidemiology Branch, NCI, 6120 Executive Boulevard, Bethesda, MD 20892.

${ }^{3}$ Correspondence: Genetic Epidemiology Branch, NCI, 6120 Executive Boulevard, Bethesda, MD 20892-7236 (phone: 301-435-3348; fax: 301-402-4498; E-mail: bromleyc@exchange.nci.nih.gov).

Received March 22, 1999.

Accepted October 28, 1999.
}

weight traits (Al-Shorepy and Notter, 1996), between weight and carcass traits (Sakul et al., 1993; Thorsteinsson et al., 1994), and between survival and cumulative lamb and wool production (Nawaz et al., 1992). For selection response to be favorable in dualpurpose sheep, reliable estimates of genetic parameters are needed. The presence of undesirable genetic correlations can undermine single-trait selection. Estimates of genetic correlations among reproduction, growth, and wool traits are not complete in the literature. Therefore, the objective of this study was to estimate genetic parameters among prolificacy, growth, and wool traits in Columbia, Polypay, Rambouillet, and Targhee breeds.

\section{Materials and Methods}

\section{Animals and Management}

Data were records of animals of Columbia, Polypay, Rambouillet, and Targhee breeds measured at the United States Sheep Experiment Station, Dubois, ID. The U.S. Sheep Experiment Station developed three of these breeds: Columbia, Targhee, and Polypay. The Rambouillet contributed to the base ewe stock in devel- 
opment of the Columbia, Targhee, and Polypay breeds. The Columbia was developed in 1912 from a cross of Lincoln rams on Rambouillet ewes. The Targhee originated from crossing Rambouillet rams on cross-bred ewes of Rambouillet, Lincoln, and Corriedale germplasm followed by selection. Third-generation Targhee breeding stock were released to the public in about 1938. The Polypay breed is a four-breed composite from Dorset $\times$ Targhee and Finnsheep $\times$ Rambouillet crosses . The Polypay breed was released to the public in about 1975. The foundation Targhee and Rambouillet ewes used in creating the Polypay were not returned to the station's Targhee and Rambouillet breed lines. The breeding development of the Polypay was closed in about 1970 followed by selection and inter se mating.

The base populations were assumed to be noninbred. Preliminary analyses of these data from 1970 to 1975 indicated that the average inbreeding coefficient was less than $5 \%$ for each of these breeds. The U.S. Sheep Experiment Station maintained large populations of each of the breeds during the study. The Polypay foundation flock consisted of approximately 300 ewes and increased to a maximum of approximately 900 ewes. In all breeds and selection lines within each breed, multiple sires were used under a mating system designed to minimize inbreeding depression.

Number of animals in pedigrees and with records per breed and type of trait are shown in Table 1. Means and unadjusted standard deviations for each trait by breed are shown in Table 2. Ercanbrack and Knight (1998) have described general management of these flocks. Yearlings that lambed were mixed with mature ewes and managed as part of a range band. The ewes were lambed in sheds at Dubois during April and May. During the late spring and through summer, ewes with lambs at side were herded in one of two or three bands of grazing flocks on high-elevation mountain ranges. Lambs were weaned in early September and grazed on pastures or fields for a few weeks before moving to the feedlot, where wethers were finished. Ewes were fallgrazed on sagebrush grasslands until breeding. Rams were summer-grazed on high meadow pasture and wintered in feedlot.

Prolificacy Traits. Prolificacy data were reported for the period 1974 to 1996. Measurements are based on per ewe exposed. Prolificacy traits were observed on ewes ranging from 7 mo to $12 \mathrm{yr}$ of age at breeding. With the need for sire identity, most ewes were bred in pens for $21 \mathrm{~d}$ with single-sire matings. Following pen breeding, ewes grazed winter ranges until weather required moving them to a feedlot and were fed a lategestation diet to condition them for lambing. Ewe lambs were bred at $7 \mathrm{mo}$ of age to lamb as yearlings. Data from ewes exposed to rams and present during the subsequent lambing season were included in the analysis for prolificacy traits. A summary of prolificacy traits for the period from 1974 to 1996 is reported in Table 2 and is based on all ewes lambing. Proportion of live births was high and ranged from 97 to $100 \%$ across all birth types and breeds.

Weight Traits. Birth weight was from lambs that were born alive and survived to weaning. Individual weaning weight was adjusted to $120 \mathrm{~d}$ of age, using individual birth weight and average daily gain from birth to wean-

Table 1. Numbers of records, animals with records, and sires and dams of animals ${ }^{\mathrm{a}}$ with records for prolificacy, weight, and wool traits by breed

\begin{tabular}{|c|c|c|c|c|}
\hline \multirow[b]{2}{*}{ Trait and number } & \multicolumn{4}{|c|}{ Breed } \\
\hline & Columbia & Polypay & Rambouillet & Targhee \\
\hline \multicolumn{5}{|l|}{ Prolificacy } \\
\hline Records & 5,140 & 7,095 & 5,695 & 6,452 \\
\hline Animals with records & 1,941 & 3,261 & 2,268 & 2,402 \\
\hline Sires & 241 & 500 & 404 & 453 \\
\hline Dams & 1,129 & 1,953 & 1,337 & 1,382 \\
\hline \multicolumn{5}{|l|}{ Weight } \\
\hline Records & 7,750 & 9,524 & 9,530 & 9,321 \\
\hline Animals with records & 7,750 & 9,524 & 9,530 & 9,321 \\
\hline Sires & 263 & 246 & 451 & 492 \\
\hline Dams & 2,095 & 2,285 & 2,435 & 2,577 \\
\hline \multicolumn{5}{|l|}{ Wool } \\
\hline \multicolumn{5}{|l|}{ Fleece weight and grade } \\
\hline Records & 11,673 & 34,746 & 18,443 & 15,014 \\
\hline Animals with records & 4,239 & 13,544 & 6,434 & 5,459 \\
\hline Sires & 286 & 869 & 559 & 536 \\
\hline Dams & 1,709 & 5,462 & 2,390 & 2,203 \\
\hline \multicolumn{5}{|l|}{ Staple length } \\
\hline Records & 4,603 & 13,049 & 7,080 & 5,534 \\
\hline Animals with records & 3,271 & 11,004 & 5,475 & 4,435 \\
\hline Sires & 276 & 784 & 531 & 511 \\
\hline Dams & 1,406 & 4,648 & 2,110 & 1,855 \\
\hline
\end{tabular}

${ }^{a}$ Numbers of animals in pedigrees were 10,$431 ; 24,784$; 13,769; and 12,939 for Columbia, Polypay, Rambouillet, and Targee, respectively. 
Bromley et al.

Table 2. Unadjusted means and standard deviations (SD) of prolificacy, weight, and wool traits for Columbia, Polypay, Rambouillet, and Targhee breeds

\begin{tabular}{|c|c|c|c|c|c|c|c|c|}
\hline \multirow[b]{2}{*}{ Trait } & \multicolumn{2}{|c|}{ Columbia } & \multicolumn{2}{|c|}{ Polypay } & \multicolumn{2}{|c|}{ Rambouillet } & \multicolumn{2}{|c|}{ Targhee } \\
\hline & Mean & $\mathrm{SD}$ & Mean & SD & Mean & SD & Mean & SD \\
\hline \multicolumn{9}{|c|}{ Prolificacy traits (trait of ewe) } \\
\hline Live births, $\mathrm{n}$ & 1.60 & .59 & 1.84 & .68 & 1.63 & .59 & 1.58 & .58 \\
\hline Litter size born, $\mathrm{n}$ & 1.61 & .59 & 1.84 & .67 & 1.63 & .59 & 1.58 & .57 \\
\hline Litter size at weaning, $\mathrm{n}$ & 1.28 & .64 & 1.39 & .66 & 1.28 & .64 & 1.22 & .64 \\
\hline \multicolumn{9}{|l|}{ Weight traits (trait of lamb) } \\
\hline Birth weight, kg & 5.0 & .9 & 4.0 & .8 & 4.7 & .8 & 5.0 & .9 \\
\hline Weaning weight, $\mathrm{kg}$ & 36.4 & 6.8 & 33.7 & 6.0 & 32.7 & 5.8 & 33.8 & 6.7 \\
\hline Average daily gain, $\mathrm{g}$ & 262 & 53 & 247 & 47 & 233 & 45 & 241 & 53 \\
\hline \multicolumn{9}{|l|}{ Wool traits } \\
\hline Fleece weight, kg & 5.1 & 1.1 & 3.8 & 1.1 & 4.6 & 1.1 & 4.8 & 1.1 \\
\hline Fleece grade & 57.4 & 2.6 & 57.7 & 3.1 & 61.5 & 2.8 & 59.6 & 2.6 \\
\hline Staple length, cm & 8.3 & 3.3 & 7.8 & 3.2 & 7.2 & 2.9 & 7.9 & 3.2 \\
\hline
\end{tabular}

ing. Average daily gain was calculated as the difference in weight between weaning and birth divided by age in days at weaning.

Wool Traits. Shearing was conducted in late May at the headquarters facility. Fleeces were weighed with belly and face wool removed (greasy fleece weight). Staple length was measured on ewe and ram lambs, all ewes, and mature rams (to $3 \mathrm{yr}$ ) prior to shearing at midside without stretching the fiber. Before 1990, three staple length measures were taken at midside by different individuals and averaged. Since 1990, only one midside measurement has been taken. Fleeces were visually graded, sorted, and bagged by quality grade. Fleece grade was assigned immediately after shearing and expressed as a visual estimate of the USDA spinning count grade. Day and year shorn were recorded.

\section{Statistical Analyses}

All analyses were done separately for each breed. Individual models were developed for each trait and then extended to the various combinations of two-trait models. Effects that explained less than .01 of total variance were dropped from the model for bivariate analyses. Sets of analyses were first conducted within each of three groups of traits. The first group was prolificacy traits and included number of live births, litter size at birth, and litter size at weaning. The second group was weight traits of lambs and included birth weight, weaning weight, and average daily gain to weaning. The third group was wool traits and included fleece weight, fleece grade, and staple length. Other sets of analyses were then conducted separately for each breed for pairs of traits from different groups of traits.

Prolificacy Traits. The basic linear model for prolificacy traits was

$$
\mathbf{y}=\mathbf{X} \boldsymbol{\beta}+\mathbf{Z}_{\mathrm{a}} \mathbf{a}+\mathbf{Z}_{\mathrm{pe}} \mathbf{p e}+\mathbf{Z}_{\mathrm{ms}} \mathbf{m s}+\varepsilon
$$

where $\mathbf{y}$ is the vector of records; $\boldsymbol{\beta}, \mathbf{a}, \mathbf{p e}$, and $\mathbf{m s}$ are vectors of fixed, additive genetic, permanent environ- mental (of animal), and mating sire effects, respectively; with association matrices $\mathbf{X}, \mathbf{Z}_{\mathrm{a}}, \mathbf{Z}_{\mathrm{pe}}$, and $\mathbf{Z}_{\mathrm{ms}}$ and $\varepsilon$ a vector of residual effects.

The fixed effect vector included effects of age of ewe at lambing and year of lambing. Age of ewe was age at the beginning of the lambing season rounded to the nearest whole year. Estimates of genetic parameters for prolificacy were on a basis of per ewe lambing. In the analysis of litter size at weaning (number of lambs weaned per ewe lambing), number of lambs present with their biological mother was the variable analyzed. Litter size at birth included live births as well as lambs that died during or shortly after birth. Live births did not include lambs dead at birth or stillborn. For litter size at weaning, the additional effect of foster code was included as a fixed effect. If a lamb was raised by a foster dam, the record of that lamb was not credited to the biological mother. Records of such fostered animals were deleted from analyses of weight traits. For litter size at weaning, a foster code was assigned as a covariate ( 1 if a ewe did not foster a lamb and 2 if a ewe did foster an additional lamb).

The (co)variance structure for random effects for prolificacy traits was

$$
\mathbf{V}\left[\begin{array}{l}
\mathbf{a} \\
\mathbf{p e} \\
\mathbf{m s} \\
\mathbf{e}
\end{array}\right]=\left[\begin{array}{llll}
\mathbf{A} \boldsymbol{\sigma}_{\mathrm{a}}^{2} & 0 & 0 & 0 \\
0 & \mathbf{I}_{\mathrm{pe}} \sigma_{\mathrm{pe}}^{2} & 0 & 0 \\
0 & 0 & \mathbf{I}_{\mathrm{ms}} \boldsymbol{\sigma}_{\mathrm{ms}}^{2} & 0 \\
0 & 0 & 0 & \mathbf{I}_{\mathrm{n}} \sigma_{\mathrm{e}}^{2}
\end{array}\right]
$$

where $\mathbf{A}$ is the numerator relationship matrix; $\sigma_{\mathrm{a}}^{2}$ is the additive genetic variance of ewes; $\sigma^{2 \mathrm{pe}}$ is the variance of permanent environmental effects of ewes; $\sigma_{\mathrm{ms}}^{2}$ is the variance of effects associated with mating sires; $\sigma_{\mathrm{e}}^{2}$ is the residual variance; and $\mathbf{I}_{\mathrm{pe}}, \mathbf{I}_{\mathrm{ms}}$, and $\mathbf{I}_{\mathrm{n}}$ are identity matrices with order equal to the number of ewes (pe), mating sires (ms), and records (n), respectively.

Van Zyl (1998), who used the same data, reported genetic correlations between number of live births and 
litter size at birth to be nearly unity for Columbia, Polypay, Rambouillet, and Targhee sheep. The high correlation between these two traits can be explained by the fact that fewer than $2 \%$ of lambs were born dead. Brash et al. (1994) reported a direct genetic correlation of .83 between live births and litter size at birth for Australian dual-purpose and meat sheep breeds. Therefore, only analyses with litter size at birth trait are reported for the bivariate analyses of prolificacy traits with weight and wool traits.

Weight Traits. The model for weight traits was

$$
\mathbf{y}=\mathbf{X} \boldsymbol{\beta}+\mathbf{Z}_{\mathrm{a}} \mathbf{a}+\mathbf{Z}_{\mathrm{m}} \mathbf{m}+\mathbf{Z}_{\mathrm{pe}} \mathbf{p e}+\varepsilon
$$

where $\mathbf{y}$ is the vector of records; $\boldsymbol{\beta}, \mathbf{a}, \mathbf{m}$, and pe are vectors of fixed, additive direct genetic, additive maternal genetic, and permanent environmental maternal genetic effects, respectively; with association matrices $\mathbf{X}, \mathbf{Z}_{\mathrm{a}}, \mathbf{Z}_{\mathrm{m}}$, and $\mathbf{Z}_{\mathrm{pe}}$, and $\varepsilon$ is a vector of residual effects. The fixed effect vector included effects associated with sex of lamb, age of dam, and band by year combination as well as type of birth and rearing combination. One of nine types of birth and rearing combinations was assigned to each lamb to account for a lamb born as a single, twin, triplet, or quadruplet, and for being reared as an orphan or by its own or by a foster dam. To account for the grazing environment before weaning, range flock or band was combined with year in which lambs were weaned as a contemporary group effect.

The (co)variance structure of random effects for weight traits was

$$
\mathbf{V}\left[\begin{array}{l}
\mathbf{a} \\
\mathbf{m} \\
\mathbf{p e} \\
\mathbf{e}
\end{array}\right]=\left[\begin{array}{llll}
\mathbf{A} \sigma_{\mathrm{a}}^{2} & \mathbf{A} \sigma_{\mathrm{am}} & 0 & 0 \\
\mathbf{A} \sigma_{\mathrm{am}} & \mathbf{A} \sigma_{\mathrm{m}}^{2} & 0 & 0 \\
0 & 0 & \mathbf{I}_{\mathrm{pe}} \sigma_{\mathrm{pe}}^{2} & 0 \\
0 & 0 & 0 & \mathbf{I}_{\mathrm{n}} \boldsymbol{\sigma}_{\mathrm{e}}^{2}
\end{array}\right]
$$

where $\mathbf{A}$ is the numerator relationship matrix, $\sigma_{\mathrm{a}}^{2}$ is the direct additive genetic variance, $\sigma_{\mathrm{m}}^{2}$ is the maternal additive genetic variance, $\sigma_{\mathrm{am}}$ is the direct-maternal additive genetic covariance, $\sigma_{\mathrm{pe}}^{2}$ is the maternal permanent environmental variance, $\sigma_{\mathrm{e}}^{2}$ is the residual variance, and $\mathbf{I}_{\mathrm{pe}}$ and $\mathbf{I}_{\mathrm{n}}$ are identity matrices with order equal to the number of dams and records, respectively.

Estimates of genetic parameters for individual lamb weaning weight are not reported. The thesis of Van Zyl (1998), who used the same data, reported genetic correlations between lamb weaning weight and average daily gain from birth to weaning $(120 \mathrm{~d})$ to be near unity for all of the breeds. Therefore, average daily gain and weaning weight were considered essentially identical traits in this analyses and only estimates of genetic parameters for average daily gain are included here.
Wool Traits. The model for wool traits was

$$
\mathbf{y}=\mathbf{X} \boldsymbol{\beta}+\mathbf{Z}_{\mathrm{a}} \mathbf{a}+\mathbf{Z}_{\mathrm{pe}} \mathbf{p e}+\varepsilon
$$

where $\mathbf{y}$ is the vector of records; $\boldsymbol{\beta}, \mathbf{a}, \mathbf{p e}$, and $\varepsilon$ are vectors of fixed, additive animal genetic, animal permanent environmental, and residual effects, respectively; with association matrices $\mathbf{X}, \mathbf{Z}_{\mathrm{a}}$, and $\mathbf{Z}_{\mathrm{pe}}$. A dam effect to account for maternal effects was initially included in the model but was subsequently excluded because the estimate of the variance component was zero for all wool traits and breeds. Day of year shorn as an indicator of contemporary group and a combined effect of sex by age of animal by year of shearing were included as fixed effects. The (co)variance structure for wool traits was

$$
\mathbf{V}\left[\begin{array}{l}
\mathbf{a} \\
\mathbf{p e} \\
\mathbf{e}
\end{array}\right]=\left[\begin{array}{lll}
\mathbf{A} \sigma_{\mathrm{a}}^{2} & 0 & 0 \\
0 & \mathbf{I}_{\mathrm{pe}} \sigma_{\mathrm{pe}}^{2} & 0 \\
0 & 0 & \mathbf{I}_{\mathrm{n}} \boldsymbol{\sigma}^{2}
\end{array}\right]
$$

where $\mathbf{A}$ is the numerator relationship matrix, $\sigma_{\mathrm{a}}^{2}$ is the additive genetic variance, $\sigma_{\mathrm{pe}}^{2}$ is the permanent environmental variance associated with the animal, $\sigma_{\mathrm{e}}^{2}$ is the residual variance, and $\mathbf{I}_{\mathrm{pe}}$ is an identity matrix with order equal to the number of animals with records.

Bivariate Analyses. For the bivariate analyses, the final models developed from the single-trait analyses were combined with appropriate covariances between random effects in the models (Table 3 ).

Both temporary and permanent environmental covariances were estimated. Permanent environmental effects were associated with the animal for wool traits, with the ewe for analyses of pairs of prolificacy traits, and with the dam of the animal on which the trait was observed for weight traits. The estimates of variance due to permanent environmental effects for fleece grade and staple length were near zero, and, therefore, the effect was omitted from bivariate analyses for those traits.

Although environmental covariance for two traits measured at different times can be forced into the covariance between permanent environmental effects, interpretation requires some caution when one trait cannot have repeated measures (Okut et al., 1999). Because of the complete confounding between the permanent environmental and residual effects for the trait without reported measures, variance due to those effects can go to either component of variance, which also complicates interpretation of the correlations among permanent environmental effects. One way to interpret the residual and permanent environmental variances and covariances is 1) to calculate a combined environmental variance from the sum of the original residual and permanent environmental variance components and 2) to calculate an environmental correlation as in the following 
Table 3. Description of fixed and random factors in animal models associated with prolificacy, weight, and wool traits

\begin{tabular}{|c|c|c|}
\hline Trait(s) & Fixed factor & Random factor \\
\hline Litter size at birth & $\begin{array}{l}\text { Age of ewe (year) } \\
\text { Year of reproduction }\end{array}$ & $\begin{array}{l}\text { Direct genetic (ewe) } \\
\text { Permanent environmental (ewe) }\end{array}$ \\
\hline Litter size at weaning & $\begin{array}{l}\text { Age of ewe (year) } \\
\text { Year of reproduction } \\
\text { Foster code }\end{array}$ & $\begin{array}{l}\text { Direct genetic (ewe) } \\
\text { Permanent environmental (ewe) }\end{array}$ \\
\hline $\begin{array}{l}\text { Birth weight, } \mathrm{kg} \text {, and } \\
\text { weaning weight, } \mathrm{kg} \\
\text { Average daily gain, } \mathrm{g}\end{array}$ & $\begin{array}{l}\text { Sex of animal } \\
\text { Age of dam (year) } \\
\text { Band by birth year } \\
\text { Type of birth and rearing code }\end{array}$ & $\begin{array}{l}\text { Direct genetic (animal) } \\
\text { Maternal genetic (dam) } \\
\text { Permanent environmental (dam) }\end{array}$ \\
\hline Fleece weight, kg & $\begin{array}{l}\text { Age, year, and sex combination } \\
\text { Day in year shorn }\end{array}$ & $\begin{array}{l}\text { Direct genetic (animal) } \\
\text { Permanent environmental (animal) }\end{array}$ \\
\hline $\begin{array}{l}\text { Fleece grade and } \\
\text { Staple length, } \mathrm{cm}\end{array}$ & $\begin{array}{l}\text { Age, year, and sex combination } \\
\text { Day in year shorn }\end{array}$ & Direct genetic (animal) \\
\hline
\end{tabular}

formula for the environmental correlation between measures of traits $\mathrm{i}$ and $\mathrm{j}$ :

$$
\mathrm{r}_{\mathrm{e}_{\mathrm{ij}}}=\left[\mathrm{r}_{\mathrm{pe}_{\mathrm{ij}}}\left(\mathrm{pe}_{\mathrm{i}}^{2} \times \mathrm{pe}_{\mathrm{j}}^{2}\right)^{\cdot 5}\right] /\left[\left(\mathrm{pe}_{\mathrm{i}}^{2}+\mathrm{e}_{\mathrm{i}}^{2}\right)\left(\mathrm{pe}_{\mathrm{j}}^{2}+\mathrm{e}_{\mathrm{j}}^{2}\right)\right]^{\cdot 5}
$$

where $\mathrm{r}_{\mathrm{pe}_{\mathrm{ij}}}$ is the correlation between permanent environmental effects, $\mathrm{pe}_{\mathrm{i}}^{2}$ and $\mathrm{pe}_{\mathrm{j}}^{2}$ are fractions of variance due to permanent environmental effects, and $\mathrm{e}_{\mathrm{i}}^{2}$ and $\mathrm{e}_{\mathrm{j}}^{2}$ are fractions of variance due to residual effects for traits $i$ and $j$. As shown later for all pairs of traits with one trait measured once and the other trait having repeated measurements, the combined environmental correlations were all near zero even though the original correlations between permanent environmental effects may have been large.

(Co)variance components were estimated with a derivative-free REML algorithm (DFREML; Graser et al., 1987) using the MTDFREML computer programs (Boldman et al., 1995). Local convergence was considered reached when the variance of the -2 log likelihoods in the simplex was less than $10^{-6}$. Restarts at local convergence were done with global convergence declared when -2 log likelihood did not change to the third decimal.

\section{Results and Discussion}

\section{Within Trait Groups}

With the number of trait combinations in these analyses, the models for each trait were not set up to include only significant fixed factors but were general for the type of trait. With the number of degrees of freedom available, unnecessary fixed factors should not affect estimates of (co)variance components. The software used does not calculate approximations for the sampling variances.

Prolificacy Traits. Estimates of (co)variance components between different combinations of prolificacy traits are reported in Table 4. Similar estimates of direct genetic heritabilities for prolificacy traits were obtained from bivariate and single-trait analyses. For example, estimates of direct genetic heritabilities ranged from .03 to .12 for the bivariate analyses, compared with estimates of direct genetic heritabilities from .03 to .11 for the single-trait analyses. Al-Shorepy and Notter (1996) reported estimates of heritability of .05 to .10 for litter size born in a 50\% Dorset, 25\% Rambouillet, 25\% Finnsheep composite population. Fogarty (1995) reported a mean estimate of heritability of .10 for litter size from a review of 53 estimates. Estimates of variance due to permanent environmental effects of ewes as proportion of total variance were small (from .01 to .07).

Estimates of direct genetic correlation between litter size at birth and litter size at weaning were moderate to large and positive (.58 to 1.00) in agreement with Saboulard et al. (1995) who reported a genetic correlation of .86 between litter size at birth and litter size at weaning.

Estimates of heritability for prolificacy traits were low, which suggests that selection to improve reproduction in these dual-purpose sheep breeds would be slow. However, the economic value of response to selection for litter size would justify their emphasis in a selection program (Wang and Dickerson, 1991). Large positive estimates of genetic correlations between litter size at birth and weaning (.58 to 1.00 ) indicate that many of the same genes are involved in expression of these traits. Selection for any of these individual prolificacy traits would also increase genetic merit for the others.

Estimated correlations between permanent environmental effects for litter size at birth and litter size at weaning ranged from -.99 to .22 . Little inference can be derived from these estimates because of the relatively small estimates of variance components due to permanent environmental effects.

Weight Traits. Estimates of (co)variance components between birth weight and average daily gain to weaning 
Table 4. Estimates of genetic parameters ${ }^{\mathrm{a}}$ for litter size at birth (Trait 1 ) and weaning (Trait 2) from bivariate analyses

\begin{tabular}{|c|c|c|c|c|c|c|c|c|c|c|c|}
\hline Breed & $\mathrm{h}_{\mathrm{a} 1}^{2}$ & $\mathrm{~h}_{\mathrm{a} 2}^{2}$ & $\mathrm{r}_{\mathrm{a} 1 \mathrm{a} 2}$ & $\mathrm{pe}_{\mathrm{a} 1}^{2}$ & $\mathrm{pe}_{\mathrm{a} 2}^{2}$ & $\mathrm{r}_{\mathrm{pe} 1 \mathrm{pe} 2} \mathrm{e}_{\mathrm{a} 1}^{2} \mathrm{~h}_{\mathrm{a} 2}^{2}$ & $\mathrm{r}_{\mathrm{e} 1 \mathrm{e} 2}$ & $\sigma_{\mathrm{a} 1}^{2}$ & $\sigma_{\mathrm{a} 2}^{2}$ & & \\
\hline Columbia & .07 & .03 & 1.00 & .03 & .07 & .22 & .91 & .91 & .51 & .30 & .36 \\
\hline Polypay & .12 & .05 & .66 & .01 & .02 & -.99 & .87 & .98 & .42 & .37 & .35 \\
\hline Rambouillet & .08 & .06 & .68 & .04 & .04 & .24 & .87 & .90 & .45 & .27 & .34 \\
\hline Targhee & .11 & .07 & .58 & .01 & .02 & -.53 & .88 & .92 & .46 & .27 & .36 \\
\hline
\end{tabular}

${ }^{\mathrm{a}} \mathrm{h}_{\mathrm{ai}}^{2}=$ direct heritability for trait $\mathrm{i} ; \mathrm{r}_{\mathrm{a} 1 \mathrm{a} 2}=$ correlation between direct additive genetic effects; $\mathrm{pe}_{\mathrm{i}}^{2}=$ variance due to permanent environmental effects of ewes as proportion of total variance for trait $i ; r_{\mathrm{pe} 1 \mathrm{pe} 2}=$ correlation between permanent environmental effects of ewes; $\mathrm{e}_{\mathrm{i}}^{2}=$ variance due to temporary environmental effects of ewes as proportion of total variance for trait $\mathrm{i} ; \mathrm{r}_{\mathrm{e} 1 \mathrm{e} 2}=$ correlation between residual effects; $\sigma_{\mathrm{i}}^{2}=$ phenotypic variance for trait $i$.

are reported in Table 5. Estimates of direct heritabilities from bivariate and single-trait analyses were similar for average daily gain, but smaller estimates of direct heritabilities for birth weight were found for bivariate analyses in Columbia (.25 vs .18), Rambouillet (.24 vs $.19)$, and Targhee (.26 vs .22). Estimates of maternal heritability from bivariate and single-trait analyses were similar.

Estimates of genetic correlation between direct and maternal effects varied across breeds and traits. Columbia and Polypay breeds had moderate estimates of maternal genetic correlation between birth weight and average daily gain, but it was unclear why for Rambouillet and Targhee breeds the estimates were near zero. The range of estimates may be due to breed differences or to sampling variation. Estimates of variance due to permanent environmental effects of ewes as proportion of total variance also were similar in single-trait and bivariate analyses and ranged from .04 to .11.

Differences between breeds for estimates of direct genetic correlation between birth weight and average daily gain were found with the highest estimate for Polypay of .57 and the lowest estimate for Columbia of .18. If these differences are real, such differences between breeds for direct genetic correlation would suggest that different responses for direct genetic merit for birth weight might be expected in different breeds if selection is practiced for increased average daily gain or weaning weight. The low-to-moderate positive estimates of direct genetic correlation between birth weight and average daily gain suggest that animals of aboveaverage birth weight should also tend to be above average in genetic merit for average daily gain and weaning weight.

Estimates of maternal genetic correlation between birth weight and average daily gain ranged from -.03 to .40. These estimates suggest that, for Rambouillet and Targhee breeds, little correlation exists between maternal effects on birth weight and maternal effects on weaning weight or average daily gain, whereas, for Columbia and Polypay breeds, a moderate maternal genetic correlation may exist between the traits. If such estimates are not the result of sampling error, Columbia and Polypay ewes that are above genetic merit to produce lambs with higher average daily gain and weaning weight would tend also to give birth to heavier lambs.

Heritability estimates in this study were in general agreement with literature values. Estimates for heritability of birth weight were intermediate to those reported for Romanov sheep by Maria et al. (1993); crossbred sheep by Martin et al. (1980); and Hampshire, Dorset and Romanov sheep by Tosh and Kemp (1994) but were slightly higher than those reported by Näsholm and Danell (1996) for Swedish finewool sheep. Estimates for the heritability of preweaning average daily gain were smaller than those reported by Ercanbrack and Price (1977) for Rambouillet and Targhee lambs (.27 and .36 , respectively) but similar to their estimate for Columbia lambs (.08). Other studies have

Table 5. Estimates of genetic parameters ${ }^{\mathrm{a}}$ for birth weight (Trait $1, \mathrm{~kg}$ ) and average daily gain (Trait 2, g) from bivariate analyses

\begin{tabular}{|c|c|c|c|c|c|c|c|c|c|c|c|c|c|c|c|c|c|c|}
\hline Breed & $\mathrm{h}_{\mathrm{a} 1}^{2}$ & $\mathrm{~h}_{\mathrm{a} 2}^{2}$ & $\mathrm{r}_{\mathrm{a} 1 \mathrm{a} 2}$ & $\mathrm{~h}_{\mathrm{m} 1}^{2}$ & $\mathrm{~h}_{\mathrm{m} 2}^{2}$ & $\mathrm{r}_{\mathrm{m} 1 \mathrm{~m} 2}$ & $\mathrm{r}_{\mathrm{a} 1 \mathrm{~m} 1}$ & $\mathrm{r}_{\mathrm{a} 1 \mathrm{~m} 2}$ & $\mathrm{r}_{\mathrm{a} 2 \mathrm{~m} 1}$ & $\mathrm{r}_{\mathrm{a} 2 \mathrm{~m} 2}$ & $\mathrm{pe}_{1}^{2}$ & $\mathrm{pe}_{2}^{2}$ & $\mathrm{r}_{\text {pe1pe2 }}$ & $\mathrm{e}_{1}^{2}$ & $\mathrm{~h}_{2}^{2}$ & $\mathrm{r}_{\mathrm{e} 1 \mathrm{e} 2}$ & $\sigma_{1}^{2}$ & $\sigma_{2}^{2}$ \\
\hline Columbia & .18 & .07 & .18 & .24 & .04 & .38 & -.20 & -.12 & .09 & .21 & .09 & .07 & .46 & .54 & .81 & .29 & .74 & 1,701 \\
\hline Polypay & .16 & .20 & .57 & .21 & .05 & .40 & .12 & .00 & .07 & -.12 & .10 & .04 & .48 & .50 & .72 & .28 & .55 & 1,442 \\
\hline Targhee & .22 & .16 & .43 & .19 & .04 & -.03 & .08 & -.06 & .21 & .12 & .10 & .09 & .56 & .47 & .71 & .20 & .67 & 1,693 \\
\hline
\end{tabular}

${ }^{\mathrm{a}} \mathrm{h}_{\mathrm{ai}}^{2}=$ direct heritability due to trait $\mathrm{i} ; \mathrm{r}_{\mathrm{a} 1 \mathrm{a} 2}=$ correlation between direct additive genetic effects; $\mathrm{r}_{\mathrm{aimj}}=$ correlation between direct additive genetic effect of trait $i$ and maternal genetic effect of trait $j ; \mathrm{pe}_{\mathrm{i}}^{2}=$ variance due to permanent environmental effects of ewes as proportion of total variance for trait $\mathrm{i} ; \mathrm{r}_{\mathrm{pe} 1 \mathrm{pe} 2}=$ correlation between permanent environmental effects of ewes; $\mathrm{e}_{\mathrm{i}}^{2}=$ variance due to temporary environmental effects of ewes as proportion of total variance for trait $\mathrm{i} ; \mathrm{r}_{\mathrm{e} 1 \mathrm{e} 2}=$ correlation between residual effects; $\sigma_{\mathrm{i}}^{2}=$ phenotypic variance for trait $\mathrm{i}$. 
also reported small heritability estimates for preweaning gain (Harrington et al., 1962; Vogt et al., 1967; Thrift et al., 1973). Similarly, estimates for the heritability of average daily gain to weaning were similar to those for weaning weight reported by Tosh and Kemp (1994) and Al-Shorepy and Notter (1996). Al-Shorepy and Notter (1996) also reported that weaning weight was strongly influenced by maternal genetic and permanent environmental effects. Wolf et al. (1981) reported estimates of genetic correlations for crossbred lambs between direct and maternal estimates ranging from -.02 to .06 for weights at birth to $84 \mathrm{~d}$. Snowder and Glimp (1991) showed that the phenotypic correlation between the dam's milk production and the growth of her lambs decreases over time. Näsholm and Danell (1996) also reported relatively large estimates of maternal heritability for birth weight and average daily gain.

Maternal genetic effects have usually not been considered when analyzing sheep weights (Näsholm and Danell, 1994). If maternal effects are present, but not considered, estimates of direct genetic variance may include variation due to maternal genetic effects. For all four breeds, maternal genetic effects were of much more importance for birth weight than for average daily gain. When maternal genetic effects are included in the model and the direct-maternal genetic correlation is positive, estimates of direct heritability are expected to be reduced and to be increased when the direct-maternal genetic correlation is negative. In a review by Meyer (1992) of beef cattle analyses, both positive and negative estimates of direct-maternal correlations were presented. Robison (1972) pointed out that negative estimates of direct-maternal genetic correlations might be due to a failure to model environmental effects adequately. Possible negative environmental covariance between dam and offspring that is not accounted for may also bias the direct-maternal genetic correlation downward (Meyer, 1992; Swalve, 1993). Robison (1981) concluded that maternal genetic effects generally are significant for younger measurements of weight and diminish with age. Näsholm and Danell (1994) found for lamb weights at early ages that maternal heritability estimates were higher than for direct heritability and for weights at approximately $150 \mathrm{~d}$ that estimates of direct heritability were three times greater than for maternal heritability. Relatively large estimates of variance due to maternal genetic effects on birth weight were reported by Maria et al. (1993) and Näsholm and Danell (1994).

Wool Traits. Estimates of (co)variance components for pairs of wool traits are reported in Table 6. Estimates of heritabilities for fleece weight ranged from .50 to .70 , for fleece grade from .26 to .50 , and for staple length from .36 to .56, which are similar to those reported by Iman et al. (1992) and Saboulard et al. (1995) for sheep breeds similar to those in the present study.

Estimates of genetic correlation of direct genetic effects for fleece weight and fleece grade were negative (unfavorable) and ranged from -.60 for Columbia breed to -.34 for Polypay breed. Saboulard (1995) reported a similar estimate of -.38 between clean fleece weight and fleece grade among crosses of Rambouillet, Columbia, and Targhee breeds. Estimates of correlations of direct genetic effects between fleece weight and staple length were positive and ranged from .52 to .55 . Iman et al. (1992) reported a similar positive genetic correlation of .46 between staple length measures taken from the side of the animal and clean fleece weight. Estimates of correlations of direct genetic effects for fleece grade and staple length were negative and ranged from -.72 for Columbia breed to - .40 for Polypay breed. Negative genetic correlations with fleece grade suggest that there would be a decrease in the fleece grade, which indicates a increase in fiber diameter and poorer fleece quality. A negative genetic correlation between staple length and fleece grade suggests that selection for either trait would result in unfavorable genetic response for the other trait. For example, selection for staple length would decrease fleece grade by increasing fiber diameter and lowering fleece quality. Estimates of genetic correlations of fleece traits with growth traits and prolificacy of dual-purpose sheep will be of importance due to the apparent ease with which genetic progress could be accomplished through selection for fleece traits.

\section{Between Prolificacy Traits and Wool Traits}

Estimates of genetic parameters from bivariate analyses for different combinations of wool traits with litter size at birth are reported in Table 7 and with litter size at weaning in Table 8. Estimates of direct genetic heritability from these bivariate analyses were similar to estimates of direct heritability for single-trait analyses, for all traits for Polypay, Rambouillet, and Targhee breeds. Estimate of direct heritability for litter size at weaning for the Columbia breed was reduced from .03 for single-trait analysis to zero for bivariate analyses of litter size at weaning and fleece grade and for bivariate analyses of litter size at weaning and staple length. For the Columbia breed, the correlations of genetic effects between litter size at weaning and wool traits have little meaning because small estimates of direct genetic variance for litter size at weaning influenced estimates of correlations between their direct genetic effects.

Estimates of direct genetic correlations between litter size at birth and fleece weight ranged from -.18 to .07 for Polypay, Rambouillet, and Targhee breeds, with an extreme estimate of -.45 for the Columbia breed. The latter negative correlation may be due to the somewhat low estimate of direct genetic variance for litter size at birth for the Columbia breed. The small overall estimates of correlation between direct genetic effects for litter size at birth and fleece weight suggest that these two traits for practical purposes are likely to be uncorrelated and that selection for either of these two traits would be expected to have little influence on genetic merit for the other trait. 
Table 6. Estimates of genetic parameters ${ }^{\mathrm{a}}$ for fleece weight $(\mathrm{kg})$, fleece grade, and staple length $(\mathrm{cm})$ from bivariate analyses

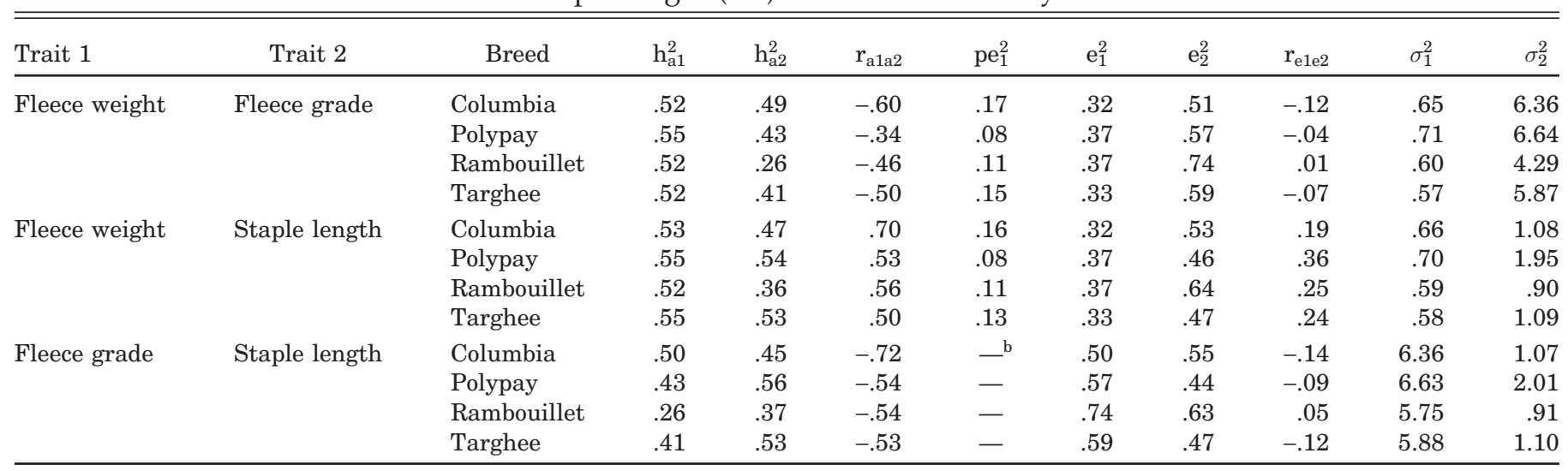

${ }^{\mathrm{a}} \mathrm{h}_{\mathrm{ai}}^{2}=$ direct heritability due to trait $\mathrm{i} ; \mathrm{r}_{\mathrm{a} 1 \mathrm{a} 2}=$ correlation between direct additive genetic effects; $\mathrm{pe}_{\mathrm{i}}^{2}=\mathrm{variance}$ due to permanent environmental effect of animals as proportion of total variance for trait $i$; $\mathrm{e}_{\mathrm{i}}^{2}=$ variance due to temporary environmental effects as proportion of total variance for trait $\mathrm{i} ; \mathrm{r}_{\mathrm{e} 1 \mathrm{e} 2}=$ correlation between residual effects of ewes; $\sigma_{\mathrm{i}}^{2}=$ phenotypic variance for trait $\mathrm{i}$.

${ }^{b}$ Effect not included in the model because estimate of variance component was nearly zero in single-trait analyses.

Estimates of direct genetic correlations between litter size at birth and coded fleece grade ranged from -.12 to .07. The results of Saboulard et al. (1995) who reported an estimate of genetic correlation of -.15 between litter size at birth and actual fleece grade (spinning count) and results from the current study suggest that these two traits are essentially genetically uncorrelated.

Estimates of direct genetic correlations between litter size at birth and staple length ranged from -.01 to .02 . These results suggest that these two traits are not genetically correlated. Selection for one group of traits is therefore unlikely to result in much change in the other group.

Estimates (Table 8) of direct genetic correlations between litter size at weaning and fleece weight ranged from -.20 to .10, except for Columbia. Saboulard et al. (1995) reported an estimate of genetic correlation of .17 between litter size at weaning and clean fleece weight.

Estimates of direct genetic correlations between litter size at weaning and fleece grade ranged from -.15 to .09 , except for the extreme estimate of .96 for Columbia. Saboulard et al. (1995) reported an estimate of genetic correlation of -.24 between litter size at weaning and fleece grade. Selection to improve genetic merit of either litter size at weaning or fleece grade would not seem likely to influence genetic response in the other trait.

Estimates of direct genetic correlations between litter size at weaning and staple length ranged from -.18 to .02 , with Columbia excepted. The estimates over all breeds suggest that these two traits are effectively genetically uncorrelated.

Table 7. Estimates of genetic parameters ${ }^{\mathrm{a}}$ for litter size at birth (Trait 1) with fleece weights $(\mathrm{kg})$, fleece grade, and staple length $(\mathrm{cm})$ from bivariate analyses

\begin{tabular}{|c|c|c|c|c|c|c|c|c|c|c|c|}
\hline Trait 2 & Breed & $\mathrm{h}_{\mathrm{a} 1}^{2}$ & $\mathrm{~h}_{\mathrm{a} 2}^{2}$ & $\mathrm{r}_{\mathrm{a} 1 \mathrm{a} 2}$ & $\mathrm{pe}_{1}^{2}$ & $\mathrm{pe}_{2}^{2}$ & $\mathrm{e}_{1}^{2}$ & $\mathrm{e}_{2}^{2}$ & $\mathrm{r}_{\mathrm{e} 1 \mathrm{e} 2}$ & $\sigma_{1}^{2}$ & $\sigma_{2}^{2}$ \\
\hline \multirow[t]{4}{*}{ Fleece weight } & Columbia & .07 & .47 & -.45 & .02 & .20 & .91 & .33 & .09 & .29 & .64 \\
\hline & Polypay & .14 & .53 & -.18 & .00 & .10 & .86 & .38 & .02 & .36 & .70 \\
\hline & Rambouillet & .10 & .51 & -.06 & .02 & .12 & .89 & .37 & .04 & .26 & .59 \\
\hline & Targhee & .11 & .53 & .07 & .00 & .16 & .89 & .18 & -.04 & .28 & .58 \\
\hline \multirow[t]{4}{*}{ Fleece grade } & Columbia & .07 & .49 & -.02 & .01 & $-^{\mathrm{b}}$ & .91 & .51 & $-^{\mathrm{b}}$ & .29 & 6.33 \\
\hline & Polypay & .14 & .42 & -.02 & .00 & - & .86 & .58 & - & .36 & 6.59 \\
\hline & Rambouillet & .09 & .25 & -.12 & .01 & - & .89 & .75 & - & .26 & 5.74 \\
\hline & Targhee & .11 & .41 & .07 & .00 & - & .88 & .59 & - & .27 & 5.87 \\
\hline \multirow[t]{4}{*}{ Staple length } & Columbia & .07 & .41 & -.01 & .02 & $-^{\mathrm{b}}$ & .91 & .59 & $-^{\mathrm{b}}$ & .29 & 1.04 \\
\hline & Polypay & .14 & .53 & .02 & .00 & - & .86 & .47 & - & .36 & 1.98 \\
\hline & Rambouillet & .09 & .36 & -.01 & .02 & - & .89 & .64 & - & .26 & .91 \\
\hline & Targhee & .11 & .53 & .01 & .01 & - & .88 & .47 & - & .27 & 1.10 \\
\hline
\end{tabular}

\footnotetext{
${ }^{\mathrm{a}} \mathrm{h}_{\mathrm{ai}}^{2}=$ direct heritability for trait $\mathrm{i} ; \mathrm{r}_{\mathrm{a} 1 \mathrm{a} 2}=$ correlation between direct additive genetic effects; $\mathrm{pe}_{\mathrm{i}}^{2}=$ variance due to permanent environmental effects of ewes as proportion of total variance for trait $i$; $e_{i}^{2}=$ variance due to temporary environmental effects as proportion of total variance for trait $\mathrm{i} ; \mathrm{r}_{\mathrm{e} 1 \mathrm{e} 2}=$ correlation between environmental effects; $\sigma_{\mathrm{i}}^{2}=$ phenotypic variance for trait $\mathrm{i}$.

${ }^{\mathrm{b}}$ Effect not included in the model.
} 
Table 8. Estimates of genetic parameters ${ }^{\mathrm{a}}$ for litter size at weaning (Trait 1 ) with fleece weight $(\mathrm{kg})$, fleece grade, and staple length $(\mathrm{cm})$ from bivariate analyses

\begin{tabular}{|c|c|c|c|c|c|c|c|c|c|c|c|}
\hline Trait 2 & Breed & $\mathrm{h}_{\mathrm{a} 1}^{2}$ & $\mathrm{~h}_{\mathrm{a} 2}^{2}$ & $\mathrm{r}_{\mathrm{a} 1 \mathrm{a} 2}$ & $\mathrm{pe}_{1}^{2}$ & $\mathrm{pe}_{2}^{2}$ & $\mathrm{e}_{1}^{2}$ & $\mathrm{e}_{2}^{2}$ & $\mathrm{r}_{\mathrm{e} 1 \mathrm{e} 2}$ & $\sigma_{1}^{2}$ & $\sigma_{2}^{2}$ \\
\hline \multirow[t]{4}{*}{ Fleece weight } & Columbia & .03 & .47 & -.68 & .02 & .13 & .32 & .21 & .00 & .36 & .63 \\
\hline & Polypay & .08 & .55 & .10 & .01 & .06 & .31 & .26 & -.00 & .35 & .70 \\
\hline & Rambouillet & .06 & .51 & .04 & .01 & .07 & .31 & .22 & -.00 & .34 & .59 \\
\hline & Targhee & .08 & .51 & -.20 & .00 & .09 & .33 & .19 & .00 & .36 & .56 \\
\hline \multirow[t]{4}{*}{ Fleece grade } & Columbia & .00 & .46 & .96 & .03 & $-^{\mathrm{b}}$ & .33 & 3.27 & $-^{b}$ & .36 & 6.08 \\
\hline & Polypay & .08 & .42 & .00 & .00 & - & .32 & 3.86 & - & .35 & 6.63 \\
\hline & Rambouillet & .07 & .24 & -.15 & .00 & - & .31 & 4.24 & - & .34 & 5.57 \\
\hline & Targhee & .07 & .39 & .09 & .00 & - & .33 & 3.54 & - & .35 & 5.83 \\
\hline \multirow[t]{4}{*}{ Staple length } & Columbia & .00 & .44 & -.99 & .03 & $-^{\mathrm{b}}$ & .33 & .60 & $-^{\mathrm{b}}$ & .36 & 1.08 \\
\hline & Polypay & .09 & .58 & -.18 & .00 & - & .32 & .84 & - & .35 & 2.00 \\
\hline & Rambouillet & .07 & .41 & -.17 & .00 & - & .31 & .58 & - & .34 & .97 \\
\hline & Targhee & .07 & .54 & .02 & .00 & - & .33 & .53 & - & .35 & 1.15 \\
\hline
\end{tabular}

${ }^{a} h_{\mathrm{ai}}^{2}=$ direct heritability for trait $\mathrm{i} ; \mathrm{r}_{\mathrm{a} 1 \mathrm{a} 2}=$ correlation between direct additive genetic effects; $\mathrm{pe}_{\mathrm{i}}^{2}=$ variance due to permanent environmental effects of ewes as proportion of total variance for trait $i$; $e_{i}^{2}=$ variance due to temporary environmental effects as proportion of total variance for trait $\mathrm{i} ; \mathrm{r}_{\mathrm{e} 1 \mathrm{e} 2}=$ correlation between environmental effects; $\sigma_{\mathrm{i}}^{2}=$ phenotypic variance for trait $\mathrm{i}$.

${ }^{\mathrm{b}}$ Effect not included in the model as estimate of variance was near zero in single-trait analysis.

Low estimates of direct genetic correlations between prolificacy and wool traits suggest that these traits have little or no genetic association, in general agreement with the literature review by Shelton (1998), who found that most genetic correlations between wool and lamb production traits were small and negative. However, other studies have reported a small and negative genetic correlation between number of lambs born and fleece weight for 2-yr-old Merino ewes but have reported positive correlations at older ages (Kennedy, 1967; Cloete and Heydenrych, 1987).

\section{Between Weight Traits and Prolificacy Traits}

Estimates of genetic parameters from analyses of each of two prolificacy traits with birth weight are reported in Table 9 and with average daily gain in Table 10.

For analyses of birth weight and litter size at birth, estimates of variance due to temporary environmental effects on birth weight as proportion of total variance increased from single-trait analyses to bivariate analyses. Estimates of variance due to permanent environmental effects of ewes as a proportion of total variance were similar between single-trait and bivariate analyses for litter size at birth.

For analyses of average daily gain and litter size at birth, the partition of environmental variance did not influence estimates for temporary environmental effects for Columbia, Polypay, or Targhee breeds. For the Rambouillet breed, however, estimate of variance due to temporary environmental effects as a proportion of total variance for average daily gain was .74 for singletrait analysis and zero for bivariate analysis with litter size at birth. This change was probably due to the arbitrary partition of environmental variance to the estimate of variance due to permanent environmental ef- fects of animals. For most traits, the sum of the components of variance due to permanent and temporary environmental effects was the same for the single-trait and bivariate analyses. With bivariate analyses of average daily gain and litter size at weaning, the addition to the model of permanent environmental effect for the animal did not influence estimates of variance due to temporary environmental effects. Estimates of variance due to permanent environmental effects of animals as a proportion of total variance were zero. Estimates of correlations between environmental effects on animals for average daily gain and on animal as ewe for litter size at weaning were uniformly small (.00 to .04) for all breeds after combining the permanent and temporary environmental components of variance for average daily gain.

Estimates of correlations between direct genetic and maternal genetic effects within and between weight traits are reported in the tables but are not discussed. These covariances are not expected to influence estimates of genetic correlations between direct genetic effects.

Estimates of direct genetic correlations between birth weight and litter size at birth ranged from -.01 to .26 and between birth weight and litter size at weaning ranged from -.37 to .01. These results suggest that birth weight and litter size at birth or weaning are only slightly genetically correlated, with mostly different genes involved in the expression of these two traits when the effects of litter size on birth weight are taken into account.

Estimates of direct genetic correlations between average daily gain and litter size at weaning ranged from .00 to .25 , for Polypay, Rambouillet, and Targhee breeds, with the exception of the estimate of -.82 for the Columbia breed. Estimates of genetic correlations between direct genetic effects for average daily gain 
Table 9. Estimates of genetic parameters ${ }^{\mathrm{a}}$ for birth weight (Trait $1, \mathrm{~kg}$ ) with litter size at birth and weaning from bivariate analyses

\begin{tabular}{|c|c|c|c|c|c|c|c|c|c|}
\hline Trait 2 & Breed & $\mathrm{h}_{\mathrm{a} 1}^{2}$ & $\mathrm{~h}_{\mathrm{a} 2}^{2}$ & $\mathrm{r}_{\mathrm{a} 1 \mathrm{a} 2}$ & & $\mathrm{~h}_{\mathrm{m} 1}^{2}$ & $\mathrm{r}_{\mathrm{a} 1 \mathrm{~m} 1}$ & & $\mathrm{r}_{\mathrm{a} 2 \mathrm{~m} 1}$ \\
\hline \multirow{4}{*}{ Litter size at birth } & Columbia & .24 & .07 & -.01 & & .26 & -.13 & & -.21 \\
\hline & Polypay & .16 & .13 & .03 & & .19 & .37 & & -.01 \\
\hline & Rambouillet & .21 & .09 & .26 & & .20 & .04 & & -.12 \\
\hline & Targhee & .19 & .14 & .11 & & .14 & .47 & & -.10 \\
\hline \multirow{4}{*}{ Litter size at weaning } & Columbia & .25 & .03 & -.37 & & .26 & -.13 & & .08 \\
\hline & Polypay & .16 & .06 & .01 & & .19 & .35 & & .28 \\
\hline & Rambouillet & .21 & .07 & .00 & & .21 & -.01 & & .20 \\
\hline & Targhee & .26 & .18 & -.11 & & .19 & .18 & & .04 \\
\hline Trait 2 & Breed & $\begin{array}{c}\mathrm{pe}_{1}^{2} \\
\text { (animal) }\end{array}$ & $\begin{array}{c}\mathrm{pe}_{2}^{2} \\
\text { (ewe) }\end{array}$ & $\begin{array}{c}\mathrm{pe}_{1}^{2} \\
\text { (dam) }\end{array}$ & $\mathrm{e}_{1}^{2}$ & $\mathrm{e}_{2}^{2}$ & $\begin{array}{l}\mathrm{r}_{\mathrm{e} 1 \mathrm{e} 2} \\
(\mathrm{a}, \mathrm{e})\end{array}$ & $\sigma_{1}^{2}$ & $\sigma_{2}^{2}$ \\
\hline \multirow{4}{*}{ Litter size at birth } & Columbia & .31 & .02 & .06 & .16 & .91 & .04 & .58 & .30 \\
\hline & Polypay & .07 & .01 & .09 & .43 & .86 & .04 & .42 & .37 \\
\hline & Rambouillet & .50 & .03 & .08 & .00 & .88 & .00 & .41 & .27 \\
\hline & Targhee & .32 & .00 & .08 & .19 & .86 & .02 & .52 & .27 \\
\hline \multirow{4}{*}{ Litter size at weaning } & Columbia & .11 & .06 & .06 & .36 & .91 & -.00 & .58 & .36 \\
\hline & Polypay & .12 & .02 & .09 & .38 & .93 & .01 & .42 & .35 \\
\hline & Rambouillet & .51 & .03 & .08 & .00 & .91 & .00 & .41 & .34 \\
\hline & Targhee & .14 & .01 & .09 & .28 & .92 & -.00 & .52 & .36 \\
\hline
\end{tabular}

${ }^{\mathrm{a}} \mathrm{h}_{\mathrm{ai}}^{2}=$ direct heritability for trait $\mathrm{i} ; \mathrm{r}_{\mathrm{a} 1 \mathrm{a} 2}=$ correlation between direct additive genetic effects; $\mathrm{h}_{\mathrm{m} 1}^{2}=$ maternal heritability for trait $1 ; r_{\text {aimj }}=$ correlation between direct additive genetic and maternal direct genetic effects for traits $\mathrm{i}$ and $\mathrm{j} ; \mathrm{pe}_{1}^{2}$ (animal) = variance due to permanent environmental effects of animals as proportion of total variance for trait $1 ; \mathrm{pe}_{2}^{2}$ (ewe) = variance due to direct permanent environmental effects of ewes as proportion of total variance for trait $2 ; \mathrm{pe}_{1}^{2}(\mathrm{dam})=$ variance due to maternal permanent environmental effects of dam of animal as proportion of total variance for trait $1 ; \mathrm{e}_{\mathrm{i}}^{2}=$ variance due to temporary environmental effects as proportion of total variance for trait $\mathrm{i} ; \mathrm{r}_{\mathrm{e} 1 \mathrm{e} 2}(\mathrm{a}, \mathrm{e})=$ correlation between environmental effects of ewes for trait 1 and as animals for trait $2 ; \sigma_{\mathrm{i}}^{2}=$ phenotypic variance for trait $\mathrm{i}$.

Table 10. Estimates of genetic parameters ${ }^{\mathrm{a}}$ for average daily gain (Trait $1, \mathrm{~g}$ ) and litter size at birth and weaning from bivariate analyses

\begin{tabular}{|c|c|c|c|c|c|c|c|c|c|}
\hline Trait 2 & Breed & $\mathrm{h}_{\mathrm{a} 1}^{2}$ & $\mathrm{~h}_{\mathrm{a} 2}^{2}$ & \multicolumn{2}{|c|}{$\mathrm{r}_{\mathrm{a} 1 \mathrm{a} 2}$} & $\mathrm{~h}_{\mathrm{m} 1}^{2}$ & \multicolumn{2}{|c|}{$\mathrm{r}_{\mathrm{a} 1 \mathrm{~m} 1}$} & $\mathrm{r}_{\mathrm{a} 2 \mathrm{~m} 1}$ \\
\hline Litter size at birth & Columbia & .07 & .07 & \multicolumn{2}{|c|}{-.30} & .04 & \multicolumn{2}{|c|}{.09} & .02 \\
\hline & Polypay & .20 & .12 & \multicolumn{2}{|c|}{.20} & .06 & \multicolumn{2}{|c|}{-.08} & .25 \\
\hline & Rambouillet & .10 & .09 & \multicolumn{2}{|c|}{.71} & .05 & \multicolumn{2}{|c|}{.73} & .11 \\
\hline & Targhee & .19 & .13 & \multicolumn{2}{|c|}{.03} & .07 & \multicolumn{2}{|c|}{.04} & .25 \\
\hline \multirow[t]{4}{*}{ Litter size at weaning } & Columbia & .06 & .03 & \multicolumn{2}{|c|}{-.82} & .05 & \multicolumn{2}{|c|}{.06} & .51 \\
\hline & Polypay & .20 & .05 & \multicolumn{2}{|c|}{.17} & .05 & \multicolumn{2}{|c|}{-.10} & .03 \\
\hline & Rambouillet & .11 & .06 & \multicolumn{2}{|c|}{.00} & .00 & \multicolumn{2}{|c|}{.31} & .95 \\
\hline & Targhee & .19 & .08 & \multicolumn{2}{|c|}{.25} & .05 & \multicolumn{2}{|c|}{-.06} & .36 \\
\hline Trait 2 & Breed & $\begin{array}{c}\mathrm{pe}_{1}^{2} \\
\text { (animal) }\end{array}$ & $\begin{array}{c}\mathrm{pe}_{2}^{2} \\
\text { (ewe) }\end{array}$ & $\begin{array}{c}\mathrm{pe}_{1}^{2} \\
(\mathrm{dam})\end{array}$ & $\mathrm{e}_{1}^{2}$ & $\mathrm{e}_{2}^{2}$ & $\begin{array}{l}\mathrm{r}_{\mathrm{e} 1 \mathrm{e} 2} \\
(\mathrm{a}, \mathrm{e})\end{array}$ & $\sigma_{1}^{2}$ & $\sigma_{2}^{2}$ \\
\hline \multirow[t]{4}{*}{ Litter size at birth } & Columbia & .11 & .01 & .07 & .71 & .92 & .04 & 1,662 & .30 \\
\hline & Polypay & .08 & .01 & .03 & .65 & .87 & .04 & 1,407 & .32 \\
\hline & Rambouillet & .74 & .04 & .06 & .00 & .87 & .00 & 1,252 & .27 \\
\hline & Targhee & .05 & .01 & .09 & .60 & .86 & .03 & 1,693 & .27 \\
\hline \multirow[t]{4}{*}{ Litter size at weaning } & Columbia & .00 & .06 & .07 & .82 & .91 & .01 & 1,662 & .32 \\
\hline & Polypay & .00 & .02 & .04 & .72 & .93 & .00 & 1,407 & .35 \\
\hline & Rambouillet & .00 & .03 & .07 & .74 & .91 & .00 & 1,236 & .34 \\
\hline & Targhee & .00 & .00 & .08 & .69 & .92 & .00 & 1,675 & .36 \\
\hline
\end{tabular}

${ }^{\mathrm{a}} \mathrm{h}_{\mathrm{ai}}^{2}=$ direct heritability for trait $\mathrm{i} ; \mathrm{r}_{\mathrm{a} 1 \mathrm{a} 2}=$ correlation between direct additive genetic effects; $\mathrm{h}_{\mathrm{m} 1}^{2}=$ maternal heritability for trait $1 ; r_{\text {aimj }}=$ correlation between direct additive genetic and maternal direct genetic effects for traits $\mathrm{i}$ and $\mathrm{j} ; \mathrm{pe}_{1}^{2}($ animal $)=$ variance due to permanent environmental effects of animals as proportion of total variance for trait $1 ; \mathrm{pe}_{2}^{2}$ (ewe) = variance due to direct permanent environmental effects of ewes as proportion of total variance for trait $2 ; \mathrm{pe}_{1}^{2}(\mathrm{dam})=$ variance due to maternal permanent environmental effects of dam of animal as proportion of total variance for trait $1 ; \mathrm{e}_{\mathrm{i}}^{2}=$ variance due to temporary environmental effects as proportion of total variance for trait $\mathrm{i} ; \mathrm{r}_{\mathrm{e} 1 \mathrm{e} 2}(\mathrm{a}, \mathrm{e})=$ correlation between environmental effects of ewes for trait 1 and as animals for trait $2 ; \sigma_{\mathrm{i}}^{2}=$ phenotypic variance for trait i. 
and litter size at weaning suggest that these two traits may be slightly positively correlated for Polypay and Targhee breeds, so that selection for either one of these two traits might result in some increase in genetic merit for the other trait for these two breeds. For the Rambouillet breed, these two traits seem to be uncorrelated, suggesting that selection to increase genetic merit for one trait would have little influence on genetic merit for the other trait. The estimates of genetic correlation between average daily gain and litter size at birth ranged from - .30 to .71 with an average of .15, although the estimate of .71 may be an outlier, as such a large correlation seems unlikely.

\section{Weight Traits and Wool Traits}

Estimates of genetic parameters from bivariate analyses for different combinations of wool traits with birth weight are reported in Table 11 and with average daily gain in Table 12. Estimates of direct genetic correlations between birth weight and fleece weight were small, but positive, and ranged from .17 to .23. Esti- mates of direct genetic correlations between birth weight and fleece grade were generally nearly zero and ranged from -.23 to .01. Estimates of direct genetic correlations between birth weight and staple length were uniformly moderate to small and ranged from .26 to .35 . These results suggest that a small-to-moderate genetic correlation exists between direct additive genetic effects for birth weight and staple length, with the possibility of a small genetic correlation between birth weight and fleece weight but probably little to no genetic correlation with fleece grade.

Estimates of direct genetic correlations between average daily gain and fleece weight were positive and moderate and ranged from .21 to .44 for Columbia, Rambouillet, and Targhee breeds, suggesting a small positive relationship between average daily gain and fleece weight, although, for the Polypay breed, the estimate was .04. Estimates of direct genetic correlations between average daily gain and fleece grade at birth were small but negative and ranged from - .31 to -.03 . These results suggest that average daily gain and fleece grade may be slightly negatively correlated. Estimates of di-

Table 11. Estimates of genetic parameters ${ }^{\mathrm{a}}$ for birth weight (Trait $1, \mathrm{~kg}$ ) with fleece weight $(\mathrm{kg})$, fleece grade, and style length $(\mathrm{cm})$ from bivariate analyses

\begin{tabular}{|c|c|c|c|c|c|c|c|c|c|}
\hline Trait 2 & Breed & $\mathrm{h}_{\mathrm{a} 1}^{2}$ & $\mathrm{~h}_{\mathrm{a} 2}^{2}$ & $\mathrm{r}_{\mathrm{a} 1 \mathrm{a} 2}$ & & $\mathrm{~h}_{\mathrm{m} 1}^{2}$ & \multicolumn{2}{|c|}{$\mathrm{r}_{\mathrm{a} 1 \mathrm{~m} 1}$} & $\mathrm{r}_{\mathrm{a} 2 \mathrm{~m} 1}$ \\
\hline \multirow[t]{4}{*}{ Fleece weight } & \multirow{2}{*}{$\begin{array}{l}\text { Columbia } \\
\text { Polypay }\end{array}$} & .24 & .46 & \multicolumn{2}{|l|}{-.17} & .26 & \multicolumn{2}{|c|}{-.09} & .03 \\
\hline & & .19 & .53 & .11 & & .17 & \multicolumn{2}{|c|}{.28} & .15 \\
\hline & Rambouillet & .21 & .51 & .18 & & .20 & \multicolumn{2}{|c|}{.07} & .21 \\
\hline & Targhee & .21 & .50 & .23 & & .19 & \multicolumn{2}{|c|}{.05} & .14 \\
\hline \multirow[t]{4}{*}{ Fleece grade } & \multirow{4}{*}{\multicolumn{2}{|c|}{$\begin{array}{l}\text { Columbia } \\
\text { Polypay } \\
\text { Rambouillet } \\
\text { Targhee }\end{array}$}} & .49 & -.06 & & .26 & \multicolumn{2}{|c|}{-.13} & .01 \\
\hline & & & .42 & .01 & & .19 & \multicolumn{2}{|c|}{.36} & .00 \\
\hline & & & .24 & -.23 & & .19 & \multicolumn{2}{|c|}{.09} & .03 \\
\hline & & & .39 & -.04 & & .14 & \multicolumn{2}{|c|}{.44} & .07 \\
\hline \multirow[t]{4}{*}{ Staple length } & \multirow{4}{*}{$\begin{array}{l}\text { Columbia } \\
\text { Polypay } \\
\text { Rambouillet } \\
\text { Targhee }\end{array}$} & .29 & .43 & .30 & & .27 & \multicolumn{2}{|c|}{-.18} & -.10 \\
\hline & & .18 & .54 & -.35 & & .18 & \multicolumn{2}{|c|}{.32} & -.07 \\
\hline & & .24 & .36 & .27 & & .19 & \multicolumn{2}{|c|}{.02} & .01 \\
\hline & & .28 & .54 & .26 & & .20 & \multicolumn{2}{|c|}{.12} & -.09 \\
\hline Trait 2 & Breed & $\begin{array}{c}\mathrm{pe}_{1}^{2} \\
\text { (animal) }\end{array}$ & $\begin{array}{c}\mathrm{pe}_{2}^{2} \\
\text { (animal) }\end{array}$ & $\begin{array}{c}\mathrm{pe}_{1}^{2} \\
(\mathrm{dam}) \\
\end{array}$ & $\mathrm{e}_{1}^{2}$ & $\mathrm{e}_{2}^{2}$ & $\begin{array}{l}\mathrm{r}_{\mathrm{e} 1 \mathrm{e} 2} \\
(\mathrm{a}, \mathrm{a})\end{array}$ & $\sigma_{1}^{2}$ & $\sigma_{2}^{2}$ \\
\hline \multirow[t]{4}{*}{ Fleece weight } & Columbia & .14 & .21 & .05 & .34 & .33 & .27 & .58 & .64 \\
\hline & Polypay & .06 & .09 & .11 & .42 & .37 & .00 & .43 & .70 \\
\hline & Rambouillet & .51 & .12 & .06 & .00 & .37 & .23 & .41 & .60 \\
\hline & Targhee & .52 & .13 & .08 & .00 & .37 & .07 & .41 & .59 \\
\hline \multirow[t]{4}{*}{ Fleece grade } & Columbia & $-^{\mathrm{b}}$ & $-^{\mathrm{b}}$ & .06 & .47 & .51 & $-^{\mathrm{b}}$ & .59 & 6.33 \\
\hline & Polypay & - & - & .10 & .50 & .58 & - & .42 & 6.60 \\
\hline & Rambouillet & - & - & .05 & .55 & .67 & - & .41 & 5.57 \\
\hline & Targhee & - & - & .08 & .51 & .61 & - & .52 & 5.83 \\
\hline \multirow[t]{4}{*}{ Staple length } & Columbia & $-^{\mathrm{b}}$ & $-^{\mathrm{b}}$ & .06 & .44 & .57 & $-^{\mathrm{b}}$ & .60 & 1.05 \\
\hline & Polypay & - & - & .10 & .49 & .46 & - & .43 & 1.98 \\
\hline & Rambouillet & - & - & .09 & .48 & .64 & - & .41 & .91 \\
\hline & Targhee & - & - & .08 & .41 & .46 & - & .52 & 1.11 \\
\hline
\end{tabular}

${ }^{a} h_{\mathrm{ai}}^{2}=$ Direct heritability for trait $\mathrm{i} ; \mathrm{r}_{\mathrm{a} 1 \mathrm{a} 2}=$ correlation between direct additive genetic effects; $\mathrm{h}_{\mathrm{m} 1}^{2}=$ maternal heritability for trait $1 ; r_{\text {aimj }}=$ correlation between direct additive genetic and maternal direct genetic effects for traits $\mathrm{i}$ and $\mathrm{j} ; \mathrm{pe}_{1}^{2}$ (animal) = variance due to permanent environmental effects of animals as proportion of total variance for trait $1 ; \mathrm{pe}_{2}^{2}$ (ewe) = variance due to direct permanent environmental effects of ewes as proportion of total variance for trait $2 ; \mathrm{pe}_{1}^{2}(\mathrm{dam})=$ variance due to maternal permanent environmental effects of dam of animal as proportion of total variance for trait 1 ; $\mathrm{e}_{\mathrm{i}}^{2}=$ variance due to temporary environmental effects as proportion of total variance for trait $\mathrm{i} ; \mathrm{r}_{\mathrm{e} 1 \mathrm{e} 2}(\mathrm{a}, \mathrm{e})=$ correlation between environmental effects of ewes for trait 1 and as animals for trait $2 ; \sigma_{\mathrm{i}}^{2}=$ phenotypic variance for trait $\mathrm{i}$.

${ }^{\mathrm{b}}$ Effect not included in the model. 
Table 12. Estimates of genetic parameters ${ }^{\mathrm{a}}$ for pre-weaning average daily gain (trait $1, \mathrm{~g})$ with fleece weight $(\mathrm{kg})$, fleece grade, and staple length $(\mathrm{cm})$ from bivariate analyses

\begin{tabular}{|c|c|c|c|c|c|c|c|c|c|}
\hline \multirow{5}{*}{$\frac{\text { Trait } 2}{\text { Fleece weight }}$} & Breed & $\mathrm{h}_{\mathrm{a} 1}^{2}$ & \multirow{2}{*}{$\frac{\mathrm{h}_{\mathrm{a} 2}^{2}}{.44}$} & \multicolumn{2}{|c|}{$\mathrm{r}_{\mathrm{a} 1 \mathrm{a} 2}$} & $\mathrm{~h}_{\mathrm{m} 1}^{2}$ & \multicolumn{2}{|c|}{$\mathrm{r}_{\mathrm{a} 1 \mathrm{~m} 1}$} & \multirow{2}{*}{$\frac{\mathrm{r}_{\mathrm{a} 2 \mathrm{~m} 1}}{-.08}$} \\
\hline & Columbia & .07 & & \multicolumn{2}{|c|}{.22} & .05 & \multicolumn{2}{|c|}{-.00} & \\
\hline & Polypay & \multirow{2}{*}{.22} & .54 & \multicolumn{2}{|c|}{.04} & .06 & \multicolumn{2}{|c|}{-.03} & .07 \\
\hline & Rambouillet & & .53 & \multicolumn{2}{|c|}{.44} & .08 & \multicolumn{2}{|c|}{-.01} & -.28 \\
\hline & Targhee & .16 & .51 & \multicolumn{2}{|c|}{.21} & .07 & \multicolumn{2}{|c|}{.06} & -.02 \\
\hline \multirow[t]{4}{*}{ Fleece grade } & Columbia & .04 & .46 & \multicolumn{2}{|c|}{-.31} & .05 & \multicolumn{2}{|c|}{-.05} & .19 \\
\hline & Polypay & .19 & .42 & \multicolumn{2}{|c|}{-.03} & .06 & \multicolumn{2}{|c|}{-.10} & .10 \\
\hline & Rambouillet & .11 & .24 &.- & & .04 & & & .13 \\
\hline & Targhee & .19 & .39 &.- & & .07 & & & .16 \\
\hline Staple length & Columbia & .08 & .41 & & & .04 & & & -.15 \\
\hline & Polypay & .21 & .53 & & & .05 & & & -.22 \\
\hline & Rambouillet & .11 & .36 & & & .05 & & & -.23 \\
\hline & Targhee & .19 & .54 & & & .07 & & & .14 \\
\hline Trait 2 & Breed & $\begin{array}{c}\mathrm{pe}_{1}^{2} \\
\text { (animal) }\end{array}$ & $\begin{array}{c}\mathrm{pe}_{2}^{2} \\
\text { (animal) }\end{array}$ & $\begin{array}{c}\mathrm{pe}_{1}^{2} \\
(\mathrm{dam})\end{array}$ & $\mathrm{e}_{1}^{2}$ & $\mathrm{e}_{2}^{2}$ & $\begin{array}{l}\mathrm{r}_{\mathrm{e} 1 \mathrm{e} 2} \\
(\mathrm{a}, \mathrm{a})\end{array}$ & $\sigma_{1}^{2}$ & $\sigma_{2}^{2}$ \\
\hline Fleece weight & Columbia & .22 & .23 & .06 & .60 & .32 & .30 & 1662 & .65 \\
\hline & Polypay & .17 & .08 & .04 & .53 & .38 & .21 & 1427 & .70 \\
\hline & Rambouillet & .18 & .12 & .07 & .53 & .35 & .20 & 1239 & .60 \\
\hline & Targhee & .52 & .15 & .08 & .14 & .35 & .21 & 1691 & .55 \\
\hline Fleece grade & Columbia & $-^{\mathrm{b}}$ & $-^{\mathrm{b}}$ & .08 & .82 & .54 & $-^{\mathrm{b}}$ & 1691 & 6.08 \\
\hline & Polypay & - & - & .03 & .73 & .58 & - & 1405 & 6.59 \\
\hline & Rambouillet & - & - & .07 & .73 & .76 & - & 1234 & 5.57 \\
\hline & Targhee & - & - & .08 & .65 & .61 & - & 1696 & 5.83 \\
\hline Staple length & Columbia & $-^{\mathrm{b}}$ & $-^{\mathrm{b}}$ & .07 & .80 & .59 & $-^{\mathrm{b}}$ & 1668 & 1.04 \\
\hline & Polypay & - & - & .03 & .71 & .47 & - & 1413 & 1.98 \\
\hline & Rambouillet & - & - & .06 & .73 & .64 & - & 1245 & .91 \\
\hline & Targhee & - & - & .08 & .65 & .46 & - & 1697 & 1.15 \\
\hline
\end{tabular}

${ }^{\mathrm{a}} \mathrm{h}_{\mathrm{ai}}^{2}=$ Direct heritability for trait $\mathrm{i} ; \mathrm{r}_{\mathrm{a} 1 \mathrm{a} 2}=$ correlation between direct additive genetic effects; $\mathrm{h}_{\mathrm{m} 1}^{2}=$ maternal heritability for trait $1 ; r_{a i m j}=$ correlation between direct additive genetic and maternal direct genetic effects for traits $\mathrm{i}$ and $\mathrm{j} ; \mathrm{pe}_{1}^{2}$ (animal) = variance due to permament environmental effects of animals as proportion of total variance for trait $1 ; \mathrm{pe}_{2}^{2}$ (ewe) = variance due to direct permanent environmental effects of ewes as proportion of total variance for trait $2 ; \mathrm{pe}_{1}^{2}(\mathrm{dam})=$ variance due to maternal permanent environmental effects of dam of animal as proportion of total variance for trait 1 ; $\mathrm{e}_{\mathrm{i}}^{2}=$ variance due to temporary environmental effects as proportion of total variance for trait $\mathrm{i} ; \mathrm{r}_{\mathrm{e} 1 \mathrm{e} 2}(\mathrm{a}, \mathrm{e})=$ correlation between environmental effects of ewes for trait 1 and as animals for trait $2 ; \sigma_{i}^{2}=$ phenotypic variance for trait $i$.

${ }^{b}$ Effect not included in the model.

rect genetic correlations between average daily gain and staple length were uniformly positive and moderate to low, ranging from .19 to .36. Lasley (1978), however, reported on studies in which a negative genetic correlation between staple length and average daily gain had been found. Selection to improve genetic merit for either average daily gain or staple length may have some influence on genetic response in the other trait. The moderate-to-high heritability estimate associated with staple length suggests that genetic progress through selection for this trait would be relatively easy. Correlated response in genetic merit for average daily gain could be achieved through selection for increased staple length, although, as discussed earlier, the result could be accompanied by undesirable correlated response in fleece grade.

\section{Implications}

Number of live births and litter size at birth are genetically closely related. A selection index would need to include only one of these two traits. Selection for weaning weight or average daily gain would be expected to result in a moderate positive response for direct genetic value, and a smaller response for maternal genetic value for birth weight. Selection for fleece weight would be expected to increase staple length. Selection for fleece weight or staple length would be expected to improve fleece grade. Selection to improve genetic merit for litter size at birth or at weaning would not result in a genetic response for fleece weight, fleece grade, or staple length. Selection to improve genetic merit for birth weight or average daily gain would not result in correlated genetic response for litter size at birth or at weaning. Birth weight and average daily gain are moderately and favorably genetically correlated with all wool traits.

\section{Literature Cited}

Al-Shorepy, S. A., and D. R. Notter. 1996. Genetic variation for ewe reproduction, lamb growth, and lamb scrotal circumference in a fall-lambing sheep flock. J. Anim. Sci. 74:1490-1498. 
Boldman, K. G., L. A. Kriese, S. D. Kachman, C. P. Van Tassell, and L. D. Van Vleck. 1995. A manual for the use of MTDFREML (Draft). Agric. Research Ser., USDA, Clay Center, NE.

Brash, L. D., N. M. Fogarty, S. A. Barwick, and A. R. Gilmour. 1994. Genetic parameters for Australian maternal and dual purpose meat sheep breeds. I. Live weight, wool production and reproduction in Border Leicester and related types. Aust. J. of Agric. Res. 45(2):459-468.

Cloete, S.W.P., and H. J. Heydenrych. 1987. Genetic parameters for reproductive rate in the Tygerhoek Merino flock. 2. Genetic correlations with wool and live mass traits. S. Afr. Tydskr. Veek. 17:8-13.

Dickerson, G. E. 1970. Efficiency of animal production - Molding the biological components. J. Anim. Sci. 30:849-859.

Ercanbrack, S. K., and A. D. Knight. 1998. Responses to various selection protocols for lamb production in Rambouillet, Targhee, Columbia, and Polypay sheep. J. Anim. Sci. 76:1311-1325.

Ercanbrack, S. K., and D. A. Price. 1977. Selecting for weight and rate of gain in inbred lambs. J. Anim. Sci. 44:532-541.

Fogarty, N. M. 1995. Genetic parameters for liveweight, fat and muscle measurements, wool production and reproduction in sheep: A review. Anim. Breed. Abstracts 63:143.

Graser, H-U., S. P. Smith, and B. Tier. 1987. A derivative-free approach for estimating variance components in animal models by restricted maximum likelihood. J. Anim. Sci. 64:1362-1370.

Harrington, R. B., D. G. Brothers, and J. V. Whiteman. 1962. Heritability of gain of lambs measured at different times and by different methods. J. Anim. Sci. 21:78-81.

Iman, N.Y., C. L. Johnson, W. C. Russell, and R. H. Stobart. 1992. Estimation of genetic parameters for wool fiber diameter measures. J. Anim. Sci. 70:1110-1115.

Kennedy, J. P. 1967. Genetic and phenotypic relationships between fertility and wool production in two-year old Merino ewes. Aust. J. Agric. Res. 18:515-519.

Lasley, J. F. 1978. Genetics of livestock improvement. (3rd Ed.). Prentice-Hall, Inc., Englewood Cliffs, NJ.

María, G. A., K. G. Boldman, and L. D. Van Vleck. 1993. Estimates of variances due to direct and maternal effects for growth traits of Romanov sheep. J. Anim. Sci. 71:845-849.

Martin, T. G., D. I. Sales, C. Smith, and D. Nicholson. 1980. Phenotypic and genetic parameters for lamb weights in a synthetic line of sheep. Anim. Prod. 30:261-269.

Meyer, K. 1992. Variance components due to direct and maternal genetic effects for growth traits of Australian beef cattle. Livest. Prod. Sci. 31:179-204.

Näsholm, A., and Ö. Danell. 1994. Maternal genetic effects on lamb weights. In: Proc. 5th World Congr. Genet. Appl. Livestock Prod., 18:163-166.

Näsholm, A., and Ö. Danell. 1996. Genetic relationships of lamb weight, maternal ability, and mature ewe weight in Swedish finewool sheep. J. Anim. Sci. 74:329-339.

Nawaz, M., H. H. Meyer, and D. R. Thomas. 1992. Performance of Polypay, Coopworth, and crossbred ewes: II. Survival and cumulative lamb and wool production over 4 years. J. Anim. Sci. 70:70-77.
O'Ferrall, G. J. 1976. Phenotypic and genetic parameters of productivity in Galway ewes. Anim. Prod. 23:295-297.

Okut, H., C. M. Bromley, L. D. Van Vleck, and G. D. Snowder. 1999. Genotypic expression at different ages: I. Prolificacy traits of sheep. J. Anim. Sci. 77:2357-2365.

Robison, O. W. 1972. The role of maternal genetic effects in animal breeding V: Maternal effects in swine. J. Anim. Sci. 35:1303-1315.

Robison, O. W. 1981. The influence of maternal genetic effects on the efficiency of selection - A review. Livest. Prod. Sci. 8:121-137.

Saboulard, M., W. C. Russell, and M. L. Riley. 1995. Selection for lambing rate and clean fleece weight in sheep. J. Anim. Sci. 73:3195-3198.

Sakul, H., G. E. Bradford, M. R. Dally, T. R. Famula, and C. M. Finley. 1994. Growth in sheep selected for weaning weight or litter size in a range environment. Proc. 5th World Congr. Genet. Appl. Livestock Prod. 18:59-62.

Sakul, H., M. Dally, and E. Bradford. 1993. Evaluation of Australian Merino and U. S. sheep breeds for growth and carcass traits. J. Anim. Sci. 71:363-368.

Shelton, M. 1998. A review of the nutritional efficiency of fiber production in goats and sheep and the relationship of fiber and meat production. Sheep and Goat Research J. 14:214-223.

Shelton, M., and J. W. Menzies. 1968. Genetic parameters of some performance characteristics of range fine-wool sheep. J. Anim. Sci. 27:1219-1265.

Snowder, G. D., and H. A. Glimp. 1991. Influence of breed, number of suckling lambs, and stage of lactation on ewe milk production and lamb growth under range conditions. J. Anim. Sci. 69:923-930.

Swalve, H. H. 1993. Estimation of direct and maternal (co)variance components for growth traits in Australian Simmental beef cattle. J. Anim. Breed. Genet. 110:241-252.

Thorsteinsson, S. S., S. Thorgeirsson, and O. B. Eisnatsdottir. 1994. Precision of predicting lean and fat weight from live ultrasonic measurements and genetic parameters for these measurements. Proc. 5th World Congr. Genet. Appl. Livestock Prod. 18:11-14.

Thrift, F. A., J. V. Whiteman, and D. D. Kratzer. 1973. Genetic analysis of preweaning and postweaning lamb growth traits. J. Anim. Sci. 36:640-643.

Tosh, J. J., and R. A. Kemp. 1994. Estimation of variance components for lamb weights in three sheep populations. J. Anim. Sci. 72:1184-1190.

Van Zyl, C. M. 1998. Estimation of genetic parameters for production traits of corn and dual purpose sheep. Ph.D. thesis, University of Nebraska, Lincoln.

Vogt, D. W., R. C. Carter, and W. H. McClure. 1967. Genetic and phenotypic parameter estimates involving economically important traits in sheep. J. Anim. Sci. 26:1232-1238.

Wang, C. T., and G. E. Dickerson. 1991. Simulated effects of reproductive performance on life-cycle efficiency of lamb and wool production at three lambing intervals. J. Anim. Sci. 69:4338-4347.

Wolf, B. T., C. Smith, J. W. B. King, and D. Nicholson. 1981. Genetic parameters of growth and carcass composition in crossbred lambs. Anim. Prod. 32:1-7. 